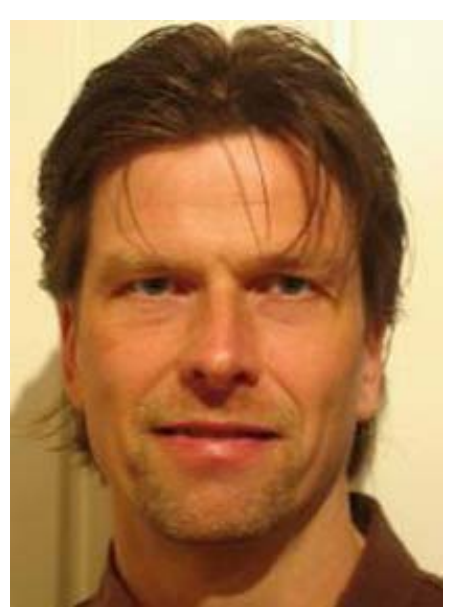

Petri Salo

\section{Työ oppimisena ja oppiminen työnä}

S tona. Edelleen ajankohtainen työssä oppimisen käsite viittaa pikemminkin menneeseen, aikaan ennen koulumuotoista ammatin oppimista. Nähdäkseni työssä oppiminen haastaa modernille, teolliselle yhteiskunnalla ja sen koulutusjärjestelmälle tyypilliset kahtiajaot ja erottelut. Nämä koskevat teorian ja käytännön, opetuksen ja oppimisen, oppilaitoksen ja työpaikan, koulutuksen ja työmarkkinoiden, yksilön ja organisaation sekä ehkä erityisesti ruumiin ja mielen välistä suhdetta.

Ehkei myöskään siirtymä fyysiseen suoritukseen perustuvasta käden ja ruumiin työstä ihmissuhde- tai tietotyöhön sinällään ole merkittävä. Kaikkeen työhön, myös käden ja ruumiin työhön, on aina liittynyt tietämisen ja osaamisen ulottuvuus. Inhimillisen elämän eri ulottuvuuksiin, myös työn eri muotoihin, fyysiseen, sosiaaliseen ja tiedolliseen voidaan suhtautua joko mekanistisen tavoiterationaalisti tai niiden erilaisia merkityksiä tulkiten ja ymmärtämän pyrkien. Niin käden ja sydämen työtä kuin kielessä tapahtuvaa mielen työtä pyrkiä kehittämään joko tiukasti raamittaen ja niukasti resursoiden tai vapausasteita luoden ja joustavuutta edistäen. Mielekäs ammattiylpeyttä ja -identiteettiä kehittävä ja vahvistava työ edellyttänee edelleen vapauteen ja joustavuuteen perustuvaa sisäistä (oppimisen) motivaatiota.

Tulkintani mukaan työssä oppimisen käsitettä käytetään usein tavalla, joka sysää osaamisen ja tekemisen vastuuta yksittäisille työn tekijöille. Kuitenkin ns. työn murroksessa näyttäisi pääasiassa olevan kyseessä työn organisoinnin, työorganisaatioden ja työmarkkinoiden murros. Työssä oppimisen sijaan meidän olisi ehkä syytä puhua pikemminkin työhön oppimisesta sekä aivan erityisesti työpaikalla, työelämässä ja työmarkkinoilla toimimisen seurauksena tapahtuvasta oppimisesta (vrt. englanninkieliset termit work related learning, workplace learning, learning in work life). Näin huomio kiinnittyisi työn tekemisen ja siitä/sen oppimisen reunaehtoihin sekä erityisesti näissä reunaehdoissa tapahtuneisiin muutoksiin.

Aikuiskasvatuksen maailmassa, oli sitten kyseessä aikuisten opettaminen tai aikuiskasvatuksen eri ilmiöiden tutkiminen, työ on aina ollut oppimista ja oppiminen työtä. Niin opettajan kuin tutkijan työ on tieto-, ihmissuhde- ja tunnetyötä. Ominaista tälle työlle on ainakin se, että se on ajasta ja paikasta riippumatonta. En viittaa tällä minkäänlaiseen transendentaaliseen tai esoteeriseen (mielen)tilaan vaan siihen, että työn tekemisen välineet ovat aina kätevästi käsillä. Ajattelua työnä ei pääse mihinkään pakoon, mutta toisaalta en koe mieleni liikkeitä kovinkaan orjuuttavina. Mitä tietotyöläinen tekee työstä vapaalla 
ajallaan tai lomallaan? Ajattelee. Kuten maatalousyhteiskunnassa myös tietoyhteiskunnassa kaikki "valoisa” hereilläoloaika on ”työaikaa”. Tästä näkökulmasta 1600 tunnin kokonaistyöaika vaikuttaa kovasti alakanttiin arvioidulta. 6200 tuntia saattaisi olla lähempänä totuutta.

$\mathrm{T}$ ieto- ja ihmissuhdetyö muuttuu ongelmalliseksi siinä vaiheessa, kun sitä pyritään organisoimaan, johtamaan, kontrolloimaan ja palkitsemaan fyysisiin suorituksiin perustuvan teollisen työn periaattein ja keinoin. Omassa työorganisaatiossani on parin viime vuoden aikana toteutettu monia merkittäviä "uudistuksia”. Näistä suurin osa on tuttuja myös yliopistomaailman ulkopuolella. Kaikki uudistukset ovat tavalla tai toisella tähdänneet siihen, että ajattelun katkeamaton virta pyritään osittamaan, määrittelemään yksiselitteisesti etukäteen, sen tuotokset standardisoimaan sekä kuvaamaan osana laajempia kokonaisprosesseja. Lopuksi prosesseille ja sen tuotoksille pyritään määrittelemään selkeät, yksiselitteiset, objektiivisiksi ja läpinäkyviksi tarkoitetut arviointikriteerit.

Tämä ajattelun ja oppimisen tuotteistaminen tehdään ja dokumentoidaan tehokkuuden, taloudellisuuden ja tuottavuuden periaatteet huomioiden. Suurin ero autotehtaan ja yliopiston välillä on se, että jälkimmäisessä kellokallena, laaduntarkkailijana ja johtajana toimii (tieto)työläinen itse. Olisiko tämä vaivihkainen antautuminen oman ajattelun ja oppimisen ulkoaohjattuun, retoriseen taivutteluun perustuvaan johtamiseen ja kontrollointiin syynä paitsi siihen, että työtyytyväisyys- ja työilmapiirimittaukset painuvat miinuksen puolelle myös siihen, että stressistä ja masennuksesta johtuvat sairauslomat ovat yleistyneet? Tällä viime vuosien työssä oppimisen jaksolla olemme, kuten tieto- ja ihmissuhdetyöntekijät aina, pistäneet taas kerran itsemme likoon. Tällä kertaa, ehkä huomaamattamme itseämme vastaan.

Y liopistoissa tapahtuvan työssä oppimisen reunaehdot on saaneet viime aikoina paljon mediajulkisuutta. En näe, että yliopisto eroaa kovinkaan paljoa muista tietotyöympäristöistä. Arja Haapakorven uusmedia-alan asiantuntijuutta ja ammattilaisuutta koskevasta artikkelista käy ilmi, että yllä esiinnostamani tietotyön organisoimisen ja johtamisen sekä näiden myötä standardoimisen ja tehostamisen käytännöt rajoittavat ammattilaisen määrittelyvaltaa, eli käytännössä myös työssä oppimisen vapautta ja mahdollisuuksia. Tekstiilitehtaalla tapahtuvaa "työssä oppimista” tutkinut Sirpa Mäkinen puolestaan toteaa sen edellyttävän sitoutunutta työorientaatiota, eli kiinnostusta oman työn ja osaamisen kehittämiseen ohi ja yli olemassa olevan työnjaon. Olen valmis yhtymään tekstiilitehtaalla kutojasta trukinkuljettajaksi siirtyneen Sarin toteamukseen työn mielekkyydestä: "Sit tää tämmönen, sanotaan niinkun joustavuus täs työssä että saa aina vähän itte miettiä, että mitä tekee.”

\section{PETRI SALO \\ psalo@abo.fi}

